\title{
Memorial Culture in Ukraine in the Context of Media Perception of Historical Problems (based on documentaries about the Holocaust and Holodomor)
}

\author{
Juergen Grimm a, Volodymyr Rizun ${ }^{b}$, Andreas Enzminger a, \\ Yurii Havrylets ${ }^{b}, *$, Sergii Tukaiev ${ }^{b}$, Maksym Khylko ${ }^{b}$, Bogdana Nosova $^{b}$ \\ a University of Vienna, Department of Communication, 1 Universitätsring, 1010 Vienna, Austria \\ b Taras Shevchenko National University of Kyiv, Institute of Journalism, 36/1 Melnikova str., \\ 04119 Kyiv, Ukraine
}

*Corresponding author's e-mail address: youri1985@gmail.com

\begin{abstract}
This study sets out the results of media effects experiment of two historical documentaries, conducted within joint research project "Broadcasting History in the Transnational Space" by the Vienna University and Taras Shevchenko National University of Kyiv researchers' team. The main objectives of the study were to explore the impact of Holocaust and Holodomor documentaries on personal traits changing, psychological inclinations, as well as on representations of historical issues. Juergen Grimm's model "Multidimensional-Imparting-of-History" (MIH) was used for assessing imparting history. The method of modelling was the basic method used during the research. It covers empirical indices of humanitarian values, national identity as well as European and Asian identification. Total of 185 student volunteers (1st to 3rd year of studies at Taras Shevchenko National University of Kyiv) were involved in the experiment. Students watched two documentaries about two major historical tragedies of the 20th century: Holocaust (Genocide of Jews) in Europe during 1939-1945 and Holodomor (Great Artificial Famine) in Ukraine during 1932-1933. Before and after being exposed to the documentaries, students filled out a questionnaire that included social-identity, national-identity as well as psychological parts. The main finding of the experiment is the students' significant predilection to compromise and reduce conflictive and aggression traits. Under the impact of both documentaries, we observed the growth of the disposition for transnational and trans-ethnic community-building (Communitas Skills) and general tendency towards cosmopolitan problem-solving and commitment for universal human rights (Political Humanitas).
\end{abstract}

KEYWORDS: memorial culture; media effect; documentary; Holodomor; Holocaust. 


\title{
Меморіальна культура в Україні у контексті медіасприйняття історичних проблем (на матеріалі документалістики про Голокост та Голодомор)
}

\author{
Грімм Юрген, Віденський університет, професор, Dr. Habil; \\ Різун Володимир Володимирович, Інститут журналістики Київського національного університету \\ імені Тараса Шевченка, професор, доктор філологічних наук;
}

Енцмінгер Андреас, Віденський університет, докторант;

Гаврилець Юрій Дмитрович, Інститут журналістики Київського наџіонального університету імені Тараса Шевченка, молодший науковий співробітник, кандидат наук із соиіальних комунікаиій;

Тукаєв Сергій Вікторович, Інститут журналістики Київського начіонального університету імені Тараса Шевченка, старший науковий співробітник, кандидат біологічних наук;

Хилько Максим Миколайович, Інститут журналістики Київського начіонального університету імені Тараса Шевченка, старший науковий співробітник, кандидат філософських наук;

Носова Богдана Миколаӥвна, Інститут журналістики Київського національного університету імені Тараса Шевченка, доиент, кандидат наук із соиіальних комунікаиій.

\section{Резюме}

У пропонованій статті подаються результати експерименту з медіаефектів історичної документалістики, проведеного в рамках міжнародного наукового проекту «Інтерпретація історичних проблем у міжнародному телемовленні» командою дослідників Віденського університету та Київського національного університету імені Тараса Шевченка. 185 студентів-добровольців були залучені до експерименту. Досліджувані переглянули документальні фільми про дві історичні трагедії: Голокост 1939-1945 pр. та Голодомор 1932-1933 рр. До і після перегляду досліджувані проходили опитування, яке містило соціально-, національно-ідентифікаційну та психодіагностичну складові. Основним результатом експерименту є виявлення зростання схильності до компромісу, а також зниження конфліктності та агресивності. Зростання показників згуртованості в рамках суспільної групи (Communitas Skills), а також вірності загальним правам людини та готовність допомагати представникам інших культур (Political Humanitas) спостерігалися під впливом обох документальних стрічок. Ключові слова: меморіальна культура; медіаефект; документальний фільм; Голодомор; Голокост.

Гримм Ю., Ризун В.В., Энцмингер А., Гаврилец Ю.Д., Тукаев С.В., Хилько М.Н., Носова Б.Н. Мемориальная культура в Украине в контексте медиавосприятия исторических проблем (на материале документалистики о Холокосте и Голодоморе).

Резюме. В данной статье приводятся результаты эксперимента по медиаэффектам исторической документалистики, проведенного в рамках международного научного проекта «Интерпретация исторических проблем в международном телевещании» командой исследователей Венского университета и Киевского национального университета имени Тараса Шевченко. 185 студентов-добровольцев приняли участие в эксперименте. Исследуемые просмотрели документальные фильмы о двух исторических трагедиях: Холокост 1939-1945 гг. и Голодомор 1932-1933 гг. До и после просмотра исследуемые отвечали на опросник, содержащий социально-, национально-идентификационную и психодиагностическую составляющие. Основным результатом эксперимента является выявленный рост склонности к компромиссу, а также снижение конфликтности и агрессивности. Рост показателей сплоченности в рамках общественной группы (Communitas Skills), а также верности общим правам человека и готовность помогать представителям других культур (Political Humanitas) наблюдался под воздействием обеих документальных лент.

Ключевые слова: мемориальная культура; медиаэффект; документальный фильм; Голодомор; Холокост. 


\section{1. Вступ}

Сьогодні історичні проблеми та їхнє відображення у свідомості суспільства є потужним елементом суспільного дискурсу та одним із найважливіших джерел формування стереотипів. Ці стереотипи під впливом мас-медій часто виникають у відповідь на пропаганду - безальтернативне, тенденційне подання єдиної точки зору, яку прийнято визнавати якщо не єдино правильною, то панівною - в тоталітарних чи авторитарних режимах. Проте здебільшого і в демократичних країнах $є$ певний основний погляд на історичні події 3 життя народу, в рамках якого зокрема у медіареципієнтів формуються стереотипи щодо «своїх» та «чужих». Такі стереотипи інтегруються у суспільну свідомість настільки глибоко, що кожна людина як медіареципієнт вважає їх органічною частиною своєї особистості.

Загалом XX століття виявилося одним із найкривавіших для людства періодів в історії. Жорстокість у небачених масштабах стала знаряддям державної політики, а смерть - товаром масового виробництва. Співвідношення і разючий контраст між культурним та науковим потенціалами, які могли служити добру, і злом, яке в результаті заподіяли політики, шокує. Ніколи раніше війни та конфлікти не поглинали стільки людських життів, ніколи раніше до душогубства методично не докладалося стільки зусиль задля досягнення цілковито безглуздих цілей.

Нещодавно американська дівчина-підліток Бреанна Мітчел після відвідання музеюмеморіалу концентраційного табору Аушвіц на території сучасної Польщі зробила на тлі табору смерті веселе селфі. Проте цей вчинок дівчини через іiї безтурботну усмішку в місці, де загинули багато людей, отримало значний розголос. Це наштовхує на думку про те, що іноді молоде покоління сприймає історію ще навіть не столітньої давності як давно забуті події. I при цьому деякі вчені наголошують на тому, що для підтримання культури історичної пам'яті суспільно важливих подій минулого слід періодично нагадувати про ці події за допомогою документальних фільмів [1]. Ф. Заромб та співавт. [2, 383] показали, що колективна пам'ять групи стійкіша, коли про історичну подію чи проблему учасники групи можуть дізнатися від своїх родичів і менш стійка, коли дізнаються 3 історичних джерел. У цій статті був порівняний вплив через документальні фільми про події та проблеми минулого, про які молодь може дізнатися від своїх родичів. Такими порівняно «свіжими» трагедіями в меморіальній культурі українців залишаються Голодомор 1932-33 рр. і Голокост під час Другої світової війни 1939-1945pp.

Тому метою дослідження $є$ порівняти ефекти впливу документальних фільмів про Голокост та Голодомор на психологічні характеристики, концепти національної ідентичності та переконання реципієнтів.

В контексті досягнення мети вважаємо за необхідне виконати такі завдання:

1) Проаналізувати актуальні наукові джерела щодо впливу документального зображення історичних проблем на процес та ефекти сприйняття реципієнтами медіаконтенту.

2) Провести експеримент із дослідження медіаефектів документальних фільмів про обидві трагедії.

3) На підставі опрацьованих експериментальних даних вивести основні тенденції медіавпливу сприйняття через документалістику обох історичних проблем.

Дослідження було проведено в рамках проекту наукової співпраці між Віденським університетом та Київським національним університетом імені Тараса Шевченка «Інтерпретація історичних проблем в міжнародному телемовленні», фінансованого державним бюджетом України та державним бюджетом Австрійської Республіки в рамках двостороннього австрійсько-українського міждержавного договору про наукову співпрацю.

Огляд попередніх досліджень. Найсуттєвіший внесок у вивчення проблем сприйняття Голокосту та інших історичних подій 20 століття зробив професор Віденського універ- 
ситету Ю. Грімм [3, 4]. На основі розробленої ним Багатовимірної моделі пізнання історії (Multidimensional Imparting History Model) науковець досліджує сприйняття проблем минулого через документалістику і показує, наскільки побачене на екрані здатне змінювати конструкти національної ідентичності через зміни у системі цінностей та переконань молодих людей. Австрійський науковець вважає: «Показ історичних подій у мас-медіа, зокрема в ефірі телебачення, зазвичай являє собою значною мірою страхітливі кадри, пов'язані з війною, катастрофами та стражданнями. А коли глядач бачить такі кадри, то воліє радше не дивитися їх, адже при цьому відчуває дискомфорт» [3, 37].

Особливості функціонування колективної пам'яті досліджував Г. Родігер [5]. Він виокремлює семантичну пам'ять, себто спільне знання, яке поділяють учасники однієї групи. «Американці, для прикладу, всі знають нинішнього Президента і мають певні знання щодо минулих Президентів». Одна з недавніх праць показує, що стійка пам'ять у американців зберігається переважно про президентів за останні 40 років із найвищими рівнями пам'яті про перших та найостанніших керівників держави США [5, 359].

Роль історичної пам'яті загалом та колективної пам'яті зокрема має значний політичний акцент. На думку А. М. Алонсо, «влада і пам'ять найтісніше пов'язані у репрезентаціях офіційних історій, які є центральними для продукування та репродукування гегемонії» [6]. Будова колективної пам'яті, на думку Г. Родігера, складається із «схематичних наративних шаблонів, або структури знань», функцією яких є розповідати історію про людей, часто наголошувати на героїчних та навіть міфічних елементах, одночасно мінімізувати негативні або непослідовні елементи» [5, 359: 7]. Теоретично осмислювали та протиставляли колективну пам'ять до поняття колективного згадування (collective remembering) та історії Дж. Верч та Г. Родігер [8].

Міжкультурні відмінності при сприйнятті певних історичних подій дуже суттєві, адже члени різних національних груп по-різному оцінюють найважливіші моменти певної історичної події. Скажімо, Дж. Верч [7] запитав американських та російських студентів вищих навчальних закладів про те, якими, на їхню думку, є 5 найважливіших моментів Другої світової війни. Цікаво, що в оцінках обох груп студентів не було жодної події, яка б повторилася, незважаючи на те, що СРСР і США у Другій світовій війні були союзниками.

При цьому є відмінності у сприйнятті подій минулого між поколіннями. Молоді люди сприймають історію, як давно минулу, так і нещодавню, відмінно від старших людей. «Молодим потрібен деякий час для осмислення історичних подій, подолання психологічного бар'єру, догм і стереотипів історичного мислення. Крім того, молоді притаманна тенденція до обмеження історичної думки лише критикою минулого, спробою звести історію суспільства до помилок і прорахунків, до суб'єктивних і волюнтаристських дій, свавілля ворогів та недругів. А це неминуче веде до відступу від історичної об'єктивності. Отже, свідомість молоді сьогодні продовжує перебувати в полоні стереотипів минулого» $[9,27-28]$. Тому дослідники особливо зацікавлені у вивченні сприйняття порівняно нещодавніх трагедій молодими людьми.

\section{2. Методи дослідження}

Голокост - масове винищення євреїв та представників інших національностей під час Другої світової війни, в рамках якого в «таборах смерті» було знищено близько 6 млн. осіб [10]. Голодомор в Україні 1932-1933 років - масовий голод в Україні, спричинений запланованою конфіскацією врожаю зернових та інших продуктів харчування у селян представниками радянської влади у 1932-1933 роках. При цьому радянська влада мала значні запаси зерна в резервах та експортувала його за кордон, блокувала виїзд голодного населення 3 України. Безпосередні втрати серед мешканців України становлять за даними Апеляційно- 
го суду міста Києва майже 4 млн. осіб, а включно з ненародженими - 10 млн. осіб [11].

Документальне історичне кіно є вагомим фрагментом медійного контенту, адже воно впливає не як художне кіно (коли людина може усвідомлювати постановочність всього зображуваного), а використання документальних кадрів із насильством і вбивствами ефективніше впливає на глядачів.

У рамках проекту «Інтерпретація історичних проблем у міжнародному телемовленні» був проведений експеримент із порівняльного вивчення сприйняття обох трагедій минулого століття українськими студентами. Серед присвячених Голокосту документальних фільмів для перегляду в рамках експерименту був обраний «Ніч i туман» («Noit et Brouillard») 1955 р. французького режисера Алана Ресне. Для демонстрування подій Голодомору 1932-1933 рр. дослідники надали перевагу стрічці «Колос правди» 2008 р. українського режисера Віктора Стеганцова.

На підставі експерименту за участі студентів Київського національного університету імені Тараса Шевченка був оцінений результат перегляду двох документальних фільмів. Ключовим стало порівняння ефектів сприйняття двох великих трагедій минулого: Голодомору 1932-1933 рр. та Голокосту 1939-1945 рр. під час Другої світової війни. Обидві ці трагедії для національної пам'яті українців є однаково важливими і рівні у меморіальній культурі українського народу. Адже як у часи Голокосту загинули багато етнічних українців, так і від Голодомору гинули євреї [12].

Багатовимірна модель пізнання історії Ю. Грімма [4] містить такі компоненти:

1. Рецептивна участь, складається з кількох компонентів: (а) формування враження (емоційне напруження, якість інформації), (b) взаємодія з наративом (ілюзія бути перенесеним в описувану реальність) [13], i (c) емоційний зв'язок між реципієнтом і комунікаційним контентом [14];

2. Навчання гуманізму, яке поділяється на чотири підгрупи вимірів: (а) зниження зовнішніх упереджень («зосереджена групова ворожнеча» проти інших груп) [15], (b) контроль агресії, яка проявляється у зниженні реактивної агресії, а також у наданні переваги на користь компромісно-орієнтованого управління конфліктами [16]; (c) Communitas Skills, які визначаються як схильність до формування транснаціональних і міжетнічних спільнот; (d) Political Humanitas, що операціоналізують як тенденцію до космополітичного вирішення проблем і відданість, прихильність до загальних прав людини;

3. Ціннісна орієнтація: вимірюється як важливість цінності на основі двох тестових методик: (a) Ціннісного тесту Шварца [17] і (b) Тесту ціннісної ієрархії [18];

4. Національна ідентичність: відповідно до DNI-тесту з трьома вимірами (а) патріотизм (згуртованість людей, що живуть в одній країні), (b) націоналізм (формування національного начала в межах групи із поступовим погіршенням ставлення до чужих груп) i космополітизм (щільність зв'язку представників національної внутрішньої групи з зовнішніми групами). Крім того, вимірюються етнічна та наднаціональна ідентифікації (асоціювання з Свропою, Азією) досліджуваних тощо.

Теоретико-методологічні межі для цього вимірювання забезпечуються моделлю «Багатовимірного пізнання історії» (Multi-Dimensional Imparting of History) (MIH) Ю. Грімма [4], яка заснована на теорії обробки інформації $[19,20]$ і переконання [21] у поєднанні 3 теоріями соціальної ідентичності [22]. На думку Ю. Грімма, «Модель МІН містить вісім вимірів, які позначають різні рівні обробки інформації, значення яких для кінцевого ефекту певної оповіді, представленої у візуальних, друкованих та інтернет-медіях можна зчитувати (...) до і після сприйняття контенту засобів масової інформації» $[3,40]$ (Рис. 1). 
Рис. 1. Мультивимірна модель пізнання історії Ю. Грімма $[3,40]$.

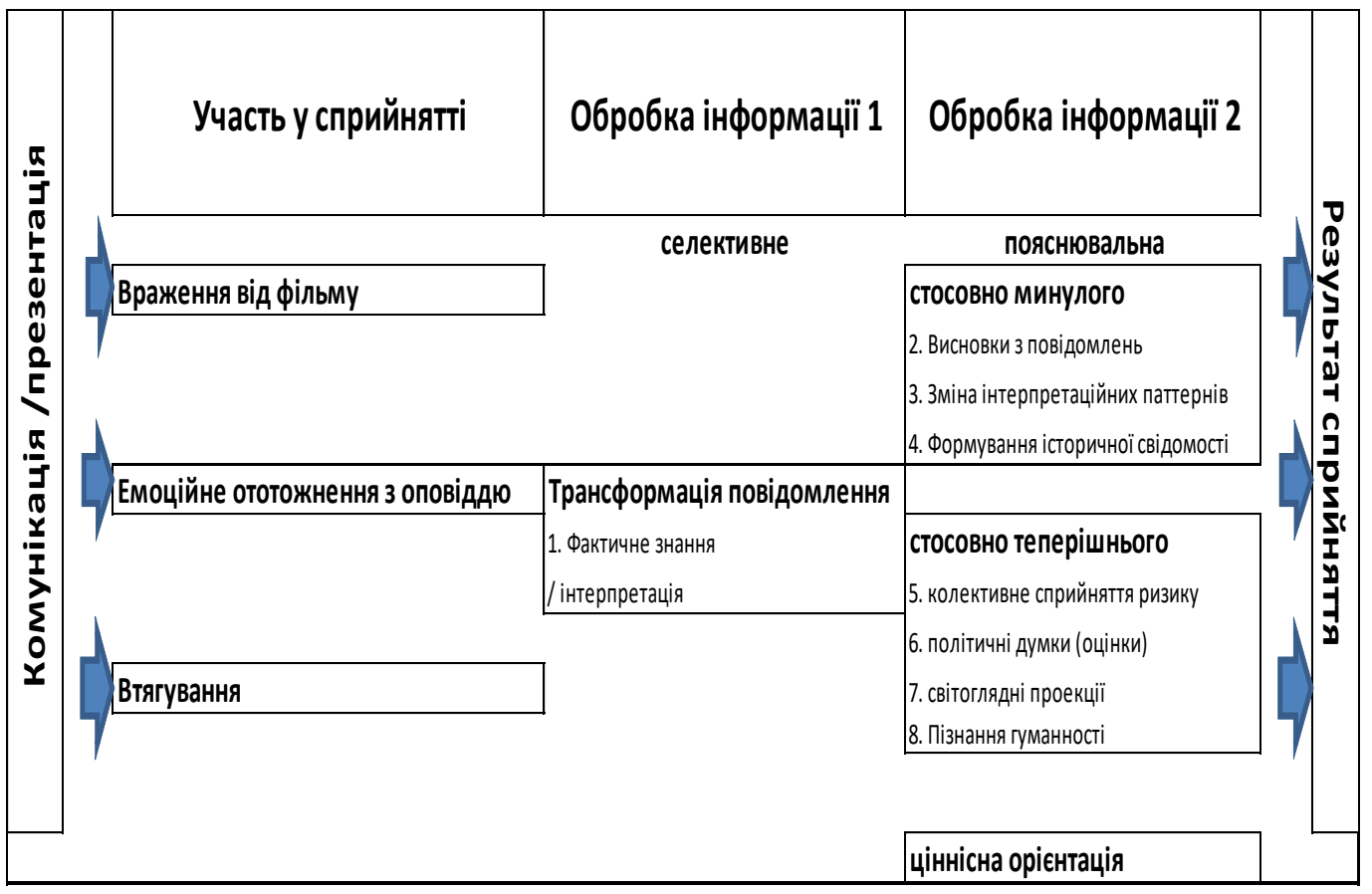

Модель МІН об'єднує змінні активності сприйняття та рівнів обробки інформації (у внутрішній колонці - один селективний рівень, у правій колонці - сім пояснювальних рівнів). Знання про факти та історичні інтерпретації в рамках комунікації можуть бути обрані або ігноруватися на першому рівні. На рівнях від 2 до 8 глядачі виробляють складні умовиводи під впливом медіаконтенту в контексті думок про минулий та теперішній часи. Це починається з активного формулювання повідомлень, які $є$ похідними від медіаконтенту, проте без прямих відповідних згадок. Структура історичної свідомості округлює процес пізнання минулих подій у таких підвимірах: (a) активний пошук додаткової історичної інформації, (b) абстракції узагальнених історичних образів (наприклад, «історія містить переважно насильство та війни») і (c) побудова історичної ідентичності («наш народ $є$ тим, чим ми стали завдяки нашій історії») [3, 40-41].

Між оцінками минулих та нинішніх подій, пов'язаних з історією, рівні від 1 до 4 впливають на свої власні та / або в комбінації твердження, які тлумачать сьогодення, що, в першу чергу, впливає на колективне усвідомлення небезпеки (рівень 5) і політичних поглядів (рівень 6), пов'язаних із минулим. Зосередження уваги на сприйнятті ризику і формуванні політичних поглядів теоретично може бути пояснено тим, що колективна пам'ять і суспільна свідомість перебувають під впливом трагедій та історичних травм, які люди переживають самі або отримують у спадок від попередніх поколінь.

Проекції реального світу [19] на сприйняття історії (рівень 7) позначають особливий випадок у МІН-моделі, як і в пов'язаній із минулим реконструкції сукупності актуальних питань, яка формує початкову точку всіх історичних згадок і передбачає відкриті часові межі, розміщені в індивідуалізованому контексті реального світу.

Пізнання гуманних цінностей (рівень 8) і орієнтовані на життя конкретної людини оцінки історії є схожими, адже обидва ці виміри містять абстрактні ідеалізації історичних подій та інтерпретацій, які потенційно (не обов'язково) збігаються. Особливо в транснаці- 
ональній експансії різних бачень історії важливою є можливість використовувати травми, війни і руйнівні конфлікти минулого продуктивно для посилення процесу цивілізації [23], який відтворює на колективному рівні гармонію та соціальну інтеграцію індивідуальних потреб у суспільстві країни-поширювача. Пізнання гуманності ділиться на чотири підгрупи рівнів у межах МІН-моделі: [15] (1) зниження упередженості у сенсі зменшення «групової сфокусованої ворожнечі» і (2) контроль агресії, яка проявляється в зниженні реактивної агресії і узаконення насильства, а також перевагу компромісного врегулювання конфліктів [24; 25]. У розширенні цих захисних варіантів пізнання гуманності $є$ такі: (3) Комунікаційні навички (Communitas Skills) і (4) політичний гуманітаризм (Political Humanitas), які є еквівалентними до диспозицій, що сприяють намірам індивіда активно стабілізувати соціально-побутові ситуації або реалізувати цю функцію в майбутньому. Комунікаційні навички визначаються як схильність до створення транснаціональних та міжетнічних спільнот. Політичний гуманітаризм охоплює, за визначенням, схильність до космополітичного вирішення проблем [26; 27; 28; 29], до якого входять три компоненти: (1) готовність надавати гуманітарну допомогу, незалежно від географічної та культурної спорідненості 3 жертвами, (2) готовність допомагати політично переслідуваним особам у своїй країні і по всьому світу і (3) вірність загальним правам людини.

Ю. Грімм розробив трикомпонентну модель оцінки національної ідентичності; динаміку національної ідентичності дослідник взяв за основу при оцінці впливу різних видів медійного контенту, в нашому випадку, історичної документалістики. Національна ідентичність, за Ю. Гріммом, має такі складові:

1. космополітизм - пов'язаність внутрішньогрупових зобов'язань із не пов'язаними 3 групою (містить 3 рівні: рефлексивність, різноманітність, глобальність);

2. патріотизм - ступінь зв'язку з Батьківщиною і людьми, які в ній проживають, ступінь внутрішньогрупових зобов'язань (містить 5 рівнів: зв'язок із країною і людьми, зв'язок із національними символами, зв'язок з історією та культурою, ідентифікація з відомими спортсменами, зв'язок із демократичною системою своєї країни);

3. націоналізм - формування внутрішньогрупових зобов'язань і одночасне применшення інших груп (має 3 рівні: загальна вищість власної групи, відокремлення групи від інших, готовність вдаватися до насильства заради інтересів власної групи).

За межами цього вузького аспекту пізнання історії, згадані концепції також впливають на загальні ціннісні орієнтації і колективні ідентичності людини (зовнішні ефекти пізнання історії). У цьому дослідженні увага зосереджена на емоційному стані глядачів у контексті глибини обробки інформації, позначеної за допомогою пізнання гуманності (8-ий вимір у моделі МІН), а також зміною ціннісних орієнтацій та конструктів національної ідентичності.

Вся вибірка досліджуваних була поділена на 5 груп, 3 з яких переглянули різні версії фільму про Голокост: 1) оригінальна версія фільму, 2) оригінальна версія, доповнена свідченнями винуватців та жертв трагедії, 3) оригінальна версія, доповнена свідченнями жертв трагедії; інші 2 групи - 2 версії фільму про Голодомор: 1) оригінальна версія фільму, з якої був вирізаний сучасний контекст вшанування суспільством жертв трагедії, 2) оригінальна версія фільму, в якій був показаний сучасний контекст вшанування суспільством жертв трагедії.

\section{3. Результати й обговорення}

Через перегляд стрічки про Голокост спостерігається достовірна тенденція зростання готовності до компромісу в конфліктних ситуаціях і зниження готовності до активної боротьби. Слабко достовірне зниження упередженості. Загалом помірним є зростання гуманності через сприйняття Голокосту стосовно подальшої конфліктної поведінки досліджува- 
них. Отже, демонстрування проблеми Голокосту через фільм допомагає розвивати орієнтовані на компроміс способи кризового менеджменту. «Це підтверджує парадигматичну роль Голокосту як важливого прикладу цивілізаційного зламу у просуванні гуманітарних цінностей» $[30,25]$.

Рис. 2. Динаміка комунікаційних навичок (Communitas Skills) та політичного гуманітаризму (Political Humanitas) в групах, які переглядали фільм про Голокост [30, $10]$.

\begin{tabular}{|c|c|c|c|c|c|c|c|c|c|}
\hline \multirow[t]{2}{*}{$\begin{array}{l}\mathrm{N}=119 ; \mathrm{G} 1=55 \mathrm{G} 2=31 \mathrm{G} 3=33 \\
\text { Post-Pre: Agreement d\% } \\
-100 \text { bis } 100 \\
\text { Agreed to } \ldots\end{array}$} & \multicolumn{2}{|c|}{$\begin{array}{c}\text { G1 } \\
\text { NF Doc }\end{array}$} & \multicolumn{2}{|c|}{$\begin{array}{l}\text { G2 } \\
\text { NF Doc + } \\
\text { witnesses } \\
\text { to history. } \\
\text { perpetrator } \\
\text { + victim }\end{array}$} & \multicolumn{2}{|c|}{$\begin{array}{c}\text { G3 } \\
\text { NF Doc + } \\
\text { witnesses } \\
\text { to history. } \\
\text { victim }\end{array}$} & \multirow[t]{2}{*}{ 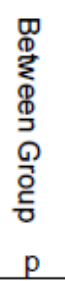 } & \multicolumn{2}{|c|}{ Total } \\
\hline & $\mathrm{p}$ & $\mathrm{d} \%$ & $\mathrm{p}$ & $\mathrm{d} \%$ & p & $\mathrm{d} \%$ & & $\mathrm{p}$ & $\mathrm{d} \%$ \\
\hline $\begin{array}{l}\text { If I see a victim, I do help in any case, } \\
\text { regardless of race and origin of the } \\
\text { person concerned. }\end{array}$ & * & $-3,9$ & * & 6,5 & & 0,9 & $!$ & & 0,1 \\
\hline $\begin{array}{l}\text { I like to party with people from } \\
\text { different cultures and backgrounds. }\end{array}$ & & $-1,3$ & & 1,8 & & 0,9 & & & 0,1 \\
\hline I prefer to party with my own kind. (-) & & 4,2 & & 3,2 & & $-0,4$ & & & 2,7 \\
\hline $\begin{array}{l}\text { I will stand up for someone who is } \\
\text { being threatened volently by another } \\
\text { person, even if I must take a risk. }\end{array}$ & & 4,2 & & 3,2 & & 4,0 & & * & 3,9 \\
\hline $\begin{array}{l}\text { I would defend a stranger in my own } \\
\text { country if he is attacked. }\end{array}$ & ** & $-5,9$ & * & 7,4 & & 3,7 & !!! & & 0,2 \\
\hline $\begin{array}{l}\text { I have got a friendly relationship to the } \\
\text { nations on earth. }\end{array}$ & & 4,7 & ** & 8,3 & & 6,3 & & ** & 6,1 \\
\hline Index Communitas & & $-1,8$ & * & 4,0 & & 1,9 & $! !$ & & 0,8 \\
\hline I stand up for human rights. & & $-0,3$ & & 3,7 & & $-3,6$ & & & $-0,1$ \\
\hline $\begin{array}{l}\text { I show commitment for people in } \\
\text { need. }\end{array}$ & * & 3,7 & ** & 7,1 & * & 5,5 & & & \\
\hline $\begin{array}{l}\text { I donate to starving children and } \\
\text { adults all around the world. }\end{array}$ & & 0,3 & & 3,2 & * & 8,9 & & & 3,4 \\
\hline $\begin{array}{l}\text { Istand up for politically persecuted } \\
\text { people and fight actively against } \\
\text { torture. }\end{array}$ & & $-0,5$ & & 3,3 & & 0,9 & & & \\
\hline $\begin{array}{l}\text { I get actively involved with the peace } \\
\text { on earth. }\end{array}$ & $* \star \star$ & 6,8 & & 6,5 & * & 12,5 & & & \\
\hline Index Political Humanitas & & 2,0 & & & & 4,8 & & $* *$ & 3,6 \\
\hline
\end{tabular}

Як бачимо на Рис. 2, в індексі комунікаційних навичок (Communitas Skills) не спостерігалося суттєвих змін. Політичний гуманітаризм (Political Humanitas) зростає суттєво, особливо в аспекті відданості глобальному миру і прихильності до нужденних людей. Люди, які вижили у трагедії Голокосту, підсилили ефект збільшення політичного гуманітаризму (Political Humanitas). Така тенденція може бути пояснена тим, що «співпережи- 
вання людям, які вижили в Голокост, трансформується на співпереживання і відданість правам людини, а також солідарність із нужденними людьми або людьми під тиском» [30, $10]$.

Рис. 3. Динаміка комунікаційних навичок (Communitas Skills) та політичного гуманітаризму (Political Humanitas) в групах, які переглядали фільм про Голодомор [30, $11]$.

\begin{tabular}{|c|c|c|c|c|c|c|c|}
\hline $\begin{array}{l}\mathrm{N}=95 ; \\
\mathrm{G} 1=38 \mathrm{G} 2=57 \\
\text { Change of agreement } \% \text {, } \\
\text { post-pre }\end{array}$ & $\begin{array}{l}\text { G1 } \\
\text { Holc }\end{array}$ & lomor & $\begin{array}{l}\text { G2 } \\
\text { Holo } \\
+ \text { relc } \\
\text { the p }\end{array}$ & $\begin{array}{l}\text { domor } \\
\text { ated to } \\
\text { oresent }\end{array}$ & 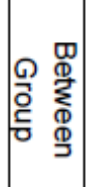 & & otal \\
\hline Agreed to ... & $\mathrm{p}$ & $\mathrm{d} \%$ & $\mathrm{p}$ & $\mathrm{d} \%$ & $\mathrm{p}$ & $\mathrm{p}$ & $\mathrm{d} \%$ \\
\hline $\begin{array}{l}\text { If I see a victim, I do help in any } \\
\text { case, regardless of race and }\end{array}$ & & $-0,8$ & & 2,0 & & & 0,9 \\
\hline $\begin{array}{l}\text { I like to party with people from } \\
\text { different cultures and } \\
\text { backgrounds. }\end{array}$ & & 2,3 & & 2,3 & & * & 2,3 \\
\hline $\begin{array}{l}\text { I prefer to party with my own } \\
\text { kind. (-) }\end{array}$ & 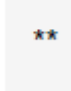 & 10,4 & * & 7,8 & & ** & 8,8 \\
\hline $\begin{array}{l}\text { I will stand up for someone who } \\
\text { is being threatened violently by } \\
\text { another person, even if I must } \\
\text { take a risk. }\end{array}$ & & $-3,9$ & & 2,0 & & & $-0,3$ \\
\hline $\begin{array}{l}\text { I would defend a stranger in my } \\
\text { own country if he is attacked. }\end{array}$ & & $-1,2$ & & $-1,3$ & & & $-1,2$ \\
\hline $\begin{array}{l}\text { I have got a friendly relationship } \\
\text { to the nations on earth. }\end{array}$ & & -1.2 & & 2,8 & & & 1,2 \\
\hline Index Communitas & ** & $-2,7)$ & & 0,0 & & & $-1,0$ \\
\hline I stand up for human rights. & & $-2,6$ & & 0,8 & & & $-0,6$ \\
\hline $\begin{array}{l}\text { I show commitment for people } \\
\text { in need. }\end{array}$ & & 1,1 & & 2,3 & & & 1,8 \\
\hline $\begin{array}{l}\text { I donate to starving children and } \\
\text { adults all around the world. } \\
\text { I stand up for politically }\end{array}$ & & $-0,4$ & & 1,3 & & & 0,6 \\
\hline $\begin{array}{l}\text { I stand up for politically } \\
\text { persecuted people and fight } \\
\text { actively against torture. }\end{array}$ & & $-0,8$ & & 1,8 & & & 0,8 \\
\hline $\begin{array}{l}\text { I get actively involved with the } \\
\text { peace on earth. }\end{array}$ & & $-0,4$ & & 3,8 & & & 2,2 \\
\hline Index Political Humanitas & & $-0,6$ & & 2,0 & & & \\
\hline
\end{tabular}

На Рис. 3 спостерігається суттєве зниження індексу комунікаційних навичок (Communitas Skills) у групі без нинішнього контексту сприйняття і вшанування трагедії Голодомору. Це може бути пояснено певним мізантропічним ефектом, який походить від шокуючої катастрофи минулого і почуття морального перенапруження (цікавим $є$ можливий протилежний ефект - десенситизація, втрата чутливості до показуваного. Якщо пода- 
ється сучасний контекст вшанування жертв трагедії Голодомору, такий мізантропічний ефект значно послаблюється [презентація, 11]. Себто важливим $є$ контекст сучасного вшанування пам'яті про жертв трагедії, тоді у молодого глядача зберігається повнота розуміння проблеми.

Рис. 4. Зміни показників національної ідентичності у групах, які переглянули фільм про Голокост [30, 13].

\begin{tabular}{|c|c|c|c|c|c|c|c|c|c|}
\hline $\begin{array}{l}\mathrm{N}=119 ; \mathrm{G} 1=55 \mathrm{G} 2=31 \mathrm{G} 3=33 \\
\text { Post-Pre: Agreement d } \% \\
-100 \text { bis } 100\end{array}$ & & & $\begin{array}{l}\mathrm{NF} \\
\text { witn } \\
\text { to hi } \\
\text { perp } \\
+\mathrm{v}\end{array}$ & $\begin{array}{l}\text { Doc + } \\
\text { Dsses } \\
\text { story. } \\
\text { etrator } \\
\text { ctim }\end{array}$ & $\begin{array}{l}\mathrm{NF} \\
\text { witne } \\
\text { to hi } \\
\text { vic }\end{array}$ & $\begin{array}{l}3 \\
\text { oc }+ \\
\text { sses } \\
\text { story. } \\
\text { im }\end{array}$ & 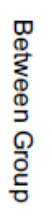 & & tal \\
\hline Dimensions of National Identiy & $p$ & $\mathrm{~d} \%$ & $\mathrm{p}$ & $d \%$ & $\mathrm{p}$ & $\mathrm{d} \%$ & $\mathrm{p}$ & $\mathrm{p}$ & $\mathrm{d} \%$ \\
\hline Bond with People \& Landcapes & * & $-2,9$ & ** & $-3,1$ & & 2,1 & ! & & $-1,6$ \\
\hline ... Sportsmen \& Symbols & * & $-2,4$ & ** & $-5,5$ & & 2,0 & ! & & $-2,0$ \\
\hline ... Culture & & 0,9 & & 1,0 & & $-1,1$ & & & 0,4 \\
\hline ... Democratic System \& History & & $-0,9$ & & $-2,3$ & & 3,1 & & & $-0,2$ \\
\hline Patriotism (total) & ** & $-1,8$ & $\star \star$ & $-2,9$ & & 2,0 & $! !$ & & $-1,0$ \\
\hline General Superiority & & $-0,4$ & & $-9,2)$ & ** & $-6,9$ & ! & ** & $-4,5$ \\
\hline Separation / Walls-up Policy & & 0,7 & & 0,4 & & $-0,7$ & $!$ & & $-2,5$ \\
\hline Readiness for Violence & & 1,3 & & $-2,1$ & & 0,7 & & & 0,2 \\
\hline Nationalism (total) & & 0,5 & ** & $-7,1$ & & $-2,4$ & $! !$ & & $2, \infty$ \\
\hline Reflexivity & & $-2,4$ & 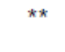 & 9,0 & & 5,5 & !! & & 2,8 \\
\hline Diversity & $\star *$ & 4,1 & 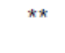 & 3,5 & *夫 & 5,6 & & 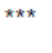 & 4,3 \\
\hline Globality & $\star \star$ & 3,7 & & 2,7 & & 3,3 & & $\star \star \star$ & 3,3 \\
\hline Cosmopolitism (total) & * & 2,1 & $\star \star \star \star$ & 3,5 & $\star \star \star \star ~$ & 4,3 & & & \\
\hline
\end{tabular}

\section{Конструкти національної ідентичності}

У контексті зазначеної в частині «Методи» структури національної ідентичності за Ю.Гріммом маємо результати, відображені на Рис. 4.

Найяскравішим результатом у групах студентів, які переглянули стрічку про Голокост, $€$ загальне статистично значуще зменшення схильності до націоналізму (вищості своєї спільноти над іншими) і зростання схильності до космополітизму (орієнтованість на загальносвітовий контекст історії), що свідчить про розуміння глядачами цієї трагедії як загальнолюдської, спрямованої проти всього людства. Також суттєво зростають показники космополітизму від перегляду фільму про Голодомор, а показники націоналізму суттєво не змінюються, незначно знижується патріотизм - ступінь зв'язку з Батьківщиною та власним народом. Пояснити цей феномен наразі не видається можливим і це потребує подальших досліджень, хоча статичної цінності він не має. 
Важливо, що ні через фільм про Голокост, ні через фільм про Голодомор у вибірках студентів не зростають показники націоналізму, вищості власної групи над іншими. Це може не бути причиною сприйняття цих трагедій минулого, а відображати миролюбну природу українського народу.

Рис. 5. Зміни показників національної ідентичності у групах, які переглянули фільм про Голодомор [30, 14].

\begin{tabular}{|c|c|c|c|c|c|c|c|}
\hline $\begin{array}{l}\mathrm{N}=95 \\
\mathrm{G} 1=38 \mathrm{G} 2=57 \\
\text { Change of agreement } \% \text {, } \\
\text { post-pre }\end{array}$ & $\begin{array}{l}\text { G1 } \\
\text { Holod }\end{array}$ & omor & $\begin{array}{l}\text { G2 } \\
\text { Holo } \\
\text { relat } \\
\text { pres }\end{array}$ & $\begin{array}{l}\text { lomor + } \\
\text { d to the } \\
\text { nt }\end{array}$ & § & & tal \\
\hline Dimensions of National Identity & $\mathrm{p}$ & $\mathrm{d} \%$ & $\mathrm{p}$ & $\mathrm{d} \%$ & $\mathrm{p}$ & $\mathrm{p}$ & $\mathrm{d} \%$ \\
\hline Bond with People \& Landscapes & ** & -3.2 & & -1.5 & & $* * * *$ & -2.2 \\
\hline ... Sportsmen \& Symbols & ** & -6.0 & & -1.2 & $!$ & ** & -3.1 \\
\hline ... Culture & & -2.6 & & 1.5 & & & -0.1 \\
\hline ... Democratic System \& History & ** & -3.4 & & 2.0 & !! & & -0.2 \\
\hline Patriotism (total) & $* * *$ & -4.1 & & 0.0 & !!! & ** & -1.6 \\
\hline General Superiority & & -4.4 & & -2.9 & & & -3.5 \\
\hline Separation / Walls-up Policy & & -0.8 & & -1.5 & & & -1.2 \\
\hline Readiness for Violence & & 5.3 & & 1.9 & & & 3.2 \\
\hline Nationalism (total) & & 0.5 & & -0.8 & & & -0.3 \\
\hline Reflexivity & & 3.6 & ** & 8.9 & & $* \star *$ & 6.8 \\
\hline Diversity & & 0.2 & ** & 3.4 & & ** & 2.2 \\
\hline Globality & & 1.8 & & 2.2 & & * & 2.0 \\
\hline Cosmopolitism (total) & & 1.5 & 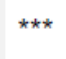 & 4.0 & & 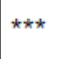 & 3.0 \\
\hline
\end{tabular}

\section{Схильність до конфліктної поведінки та упередження}

Опитувальник містив групу питань про емоції, які досліджувані відчувають до представників інших груп людей, а також упередження, пов'язані з цим.

На Рис. 6 бачимо, що в групах студентів, які дивилися фільм про Голокост, спостерігається значуще зменшення готовності фізично боротися за цінності своєї групи і значуще зростання схильності до компромісу.

Якщо порівнювати Рис. 7 з ефектами фільму про Голокост, то цікавим є значніше зниження рівня упередженості до представників інших груп, антисемітизму, расизму та сексизму саме від перегляду фільму про Голодомор. Серед українських студентів ця трагедія не викликає агресивних схильностей, що могло статися внаслідок гіпотетичного бажання помститися за страждання свого народу.

Загалом сукупний «гуманістичний» ефект фільму про Голодомор вищий, ніж фільму про Голокост, хоча жодних суттєвих агресивних схильностей не спостерігається за підсумками обох документальних стрічок. 
Рис. 6. Зміни показників конфліктної поведінки та упередженості у групах, які переглянули фільм про Голокост [30, 26].

\begin{tabular}{|c|c|c|c|c|c|c|c|c|c|}
\hline \multirow[t]{2}{*}{$\begin{array}{l}\mathrm{N}=119 ; \\
\mathrm{G} 1=55 \mathrm{G} 2=31 \mathrm{G} 3=33 \\
\text { Change of agreement } \% \text {, } \\
\text { post-pre } \\
\quad \text { Agression control }\end{array}$} & \multicolumn{2}{|c|}{$\begin{array}{c}\text { G1 } \\
\text { NF Doc }\end{array}$} & \multicolumn{2}{|c|}{$\begin{array}{c}\text { G2 } \\
\text { NF Doc + } \\
\text { witnesses to } \\
\text { history: } \\
\text { perpetrator + }\end{array}$} & \multicolumn{2}{|c|}{$\begin{array}{c}\text { G3 } \\
\text { NF Doc + } \\
\text { witnesses to } \\
\text { history: victim }\end{array}$} & \multirow[t]{2}{*}{ 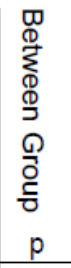 } & \multicolumn{2}{|c|}{ Total } \\
\hline & $p$ & $\mathrm{~d} \%$ & $p$ & $\mathrm{~d} \%$ & $p$ & $\mathrm{~d} \%$ & & $p$ & $\mathrm{~d} \%$ \\
\hline Reactive aggression & & -0.2 & & -0.5 & & 1.0 & & & 0.1 \\
\hline $\begin{array}{l}\text { Willingness to } \\
\text { compromise }\end{array}$ & & 4.1 & & 4.1 & * & 6.5 & & $* * *$ & 48 \\
\hline Readiness to fight & $* * *$ & -7.7 & $\star * * *$ & -12.4 & ** & -9.1 & & $* * *$ & -9.4 \\
\hline Conflict transformation & & -1.5 & & 1.4 & & 1.0 & & & -0.1 \\
\hline Antisemitism & & 0.4 & & -0.9 & & -0.7 & & & -0.3 \\
\hline Racism & & 3.2 & ** & 9.4 & & 1.3 & & ** & 4.4 \\
\hline Islamophobia & & -1.9 & & 2.3 & & -5.5 & & & -1.7 \\
\hline Xenophobia & ** & 3.7 & & 0.5 & & 4.1 & & * & 3.0 \\
\hline $\begin{array}{l}\text { Devaluation of } \\
\text { newcomers }\end{array}$ & * & 5.6 & $\star * \star *$ & 14.5 & & 2.4 & & $* * \star$ & 7.1 \\
\hline Sexism & & 3.2 & & -4.1 & & -2.1 & & & -0.1 \\
\hline $\begin{array}{l}\text { Devaluation of } \\
\text { homosexuals }\end{array}$ & $* * *$ & -6.4 & * & -7.1 & & 2.3 & & $* *$ & -4.3 \\
\hline $\begin{array}{l}\text { Devaluation of } \\
\text { homeless people }\end{array}$ & & 1.0 & * & 9.9 & $* * *$ & -12.6 & !!! & & -0.4 \\
\hline $\begin{array}{l}\text { Devaluation of disabled } \\
\text { people }\end{array}$ & ** & 7.1 & * & 6.9 & & -3.0 & & $* *$ & 4.5 \\
\hline Group Focused Enmity & & 1.8 & * & 9.9 & & -2.4 & $!$ & & 1.1 \\
\hline
\end{tabular}

\section{4. Висновки}

Основним результатом експерименту є виявлення зниження конфліктних схильностей за підсумком перегляду обох документальних фільмів. Припускаємо, що на результати вплинули особливості показуваного контенту, проте недооцінювати роль історичних проблем також не видається доцільним. Загалом у пам'яті кожного народу є певні події, які викликають негативні емоції. Деякі події минулого викликають лише співчуття, коли член суспільства чи його пращури не були безпосередньо учасниками подій; деякі справляють настільки глибоке враження, що при будь-якому згадуванні про подію через емоційнокогнітивні механізми у людини мимоволі виникають біль і найглибша скорбота.

За даними М. Дейвіса, Д. Фрідберга та В. Галлезе, такі події спричиняють шок та емпатичний стрес $[31 ; 32 ; 33]$, що, у свою чергу, може призводити до загостреної уваги та може чинити потенційно позитивний вплив на розповсюдження історичного знання і мо- 
ральний розвиток глядача. Хоча вони можуть запобігти засвоєнню реципієнтом певного знання і перешкоджати добровільному сприйняттю схожих повідомлень або обмежити тлумачення ідентичності і створити жорсткі відмінності між «ми» і «наші вороги». Проте це веде до важливого ефекту таких картин надзвичайної жорстокості. Емпатичний стрес призводить до того, що глядачі таких фото- та відеоматеріалів краще ідентифікують себе, своїх близьких і родичів із жертвами чи учасниками повідомлюваних подій. Основна мета авторів документальних історичних фільмів - уникнення повторення трагедій - стає досяжнішою за допомогою такого контенту.

Рис. 7. Зміни показників конфліктної поведінки та упередженості у групах, які переглянули фільм про Голодомор [30, 27].

\begin{tabular}{|c|c|c|c|c|c|c|c|}
\hline \multirow{2}{*}{$\begin{array}{l}\mathrm{N}=95 ; \\
\mathrm{G} 1=38 \mathrm{G} 2=57 \\
\text { Change of agreement } \% \text {, } \\
\text { post-pre } \\
\quad \text { Agression control }\end{array}$} & \multicolumn{2}{|c|}{$\begin{array}{l}\text { G1 } \\
\text { Holodomor }\end{array}$} & \multicolumn{3}{|c|}{ 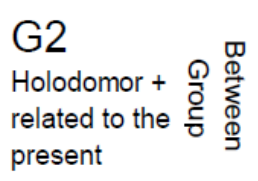 } & \multicolumn{2}{|c|}{ Total } \\
\hline & $p$ & $d \%$ & $p$ & $d \%$ & $p$ & $p$ & $d \%$ \\
\hline Reactive aggression & & 0.0 & & 1.5 & & & 0.9 \\
\hline $\begin{array}{l}\text { Willingness to } \\
\text { compromise }\end{array}$ & $* * * *$ & 7.5 & $* *$ & 4.3 & & $* * *$ & \\
\hline Readiness to fight & ** & -8.7 & $* * *$ & -8.9 & & $* * *$ & 9) \\
\hline Conflict transformation & * & 5.2 & & 0.1 & & & 2.1 \\
\hline Anti-Semitism & & -0.6 & $* * *$ & -5.6 & $!$ & ** & \\
\hline Rassism & * & -5.6 & & -1.5 & & & \\
\hline Islamophobia & & -1.0 & & -2.2 & & & \\
\hline Xenophobia & & -0.4 & & -1.4 & & & -1.0 \\
\hline $\begin{array}{l}\text { Devaluation of } \\
\text { newcomers }\end{array}$ & & 1.7 & & 0.3 & & & 0.8 \\
\hline Sexism & & -2.8 & * & -3.6 & & ** & \\
\hline $\begin{array}{l}\text { Devaluation of } \\
\text { homosexuals }\end{array}$ & & -0.2 & & -1.6 & & & -1.1 \\
\hline $\begin{array}{l}\text { Devaluation of } \\
\text { homeless people }\end{array}$ & & -3.6 & & -2.9 & & & -3.1 \\
\hline $\begin{array}{l}\text { Devaluation of disabled } \\
\text { people }\end{array}$ & & -0.8 & & 0.6 & & & 0.1 \\
\hline Group Focused Enmity & & -0.3 & * & -2.4 & & * & -1.6 \\
\hline
\end{tabular}

Основним висновком дослідження є фіксація приблизно однакового зростання схильності до космополітизму в студентської аудиторії під впливом обох документальних стрічок. Ще заслуговує уваги зростання політичного гуманітаризму (Political Humanitas) в обох групах, щоправда в групі, яка дивилася фільм про Голодомор, він зріс менше, очевидно під впливом історичної проблеми, про яку сильніше пам'ятають українці, в тому числі на родинному рівні.

Від перегляду стрічки про Голодомор спостерігається зростання готовності до комп- 
ромісу, хоча й не таке сильне, як у випадку з Голокостом. Знижується готовність до активної фізичної боротьби. Суттєво знижуються упередження до представників інших спільнот, особливо у групі, де проблеми актуалізуються для сьогодення (сьогоднішній контекст). Найсильніші ефекти - це зниження антисемітизму, расизму та сексизму під впливом перегляду стрічки «Колос правди». Сприйняття проблеми Голодомору через документальний фільм також збільшує готовність до компромісу і суттєвіше знижує упередження. Ефект сприйняття проблеми Голодомору на зміни показників гуманності навіть більший, ніж ефект від сприйняття проблеми Голокосту.

Залишаються актуальними слова італійського мислителя У. Еко у листі до онука: «Сьогодні школі слід було б навчити тебе запам'ятовувати те, що трапилося до твого народження, але їй це погано вдається. Різні опитування показують, що сучасна молодь, навіть університетська, народжена в 1990 році, не знає, а, можливо і не хоче знати про те, що відбувалося в 1980 році, вже не кажучи про те, що було 50 років тому» [Umberto Eco: "Caro nipote, studia a memoria“"]. Тому питання різних граней пам'яті суспільства про минулі трагедії залишається в фокусі уваги науковців і заслуговує подальшого вивчення в інших аспектах.

\section{References}

1. Vlasiuk, H. (2015), "How the boy from the concentration camp became a Facebook star", available at: http://zaxid.net/news/showNews.do?yak_hlopchik_z_kontstaboru_ stav_zirkoyu_facebook\&objectId=1339567 (accessed 05 November 2016).

2. Zaromb, F., Butler, A.C., Agarwal, P.K. \& Roediger, H.L.III (2014), "Collective memories of three wars in United States history in younger and older adults", Memory \& Cognition, Vol. 42, Issue 3, pp. 383-399.

3. Grimm, J. (2015), "Value orientation and national identity in Russia: A media effect study on the Holocaust documentary "Night and Fog"", Central European Journal of Communication, Vol. 1, pp. 37-62.

4. Grimm, J. (2012), "Multidimensionale Geschichtsvermittlung. Ein theoretischmethodisches Konzept zur Untersuchung von Medienwirkungen auf der Basis mediatisierter historischer Stoffe", Medien \& Zeit, no.3, pp. 30-54.

5. Roediger, H.L.III \& Abel, M. (2015), "Collective memory: a new arena of cognitive study", Trends in Cognitive Sciences, no. 19(7), pp. 359-61, doi: 10.1016/j.tics.2015.04.003.

6. Alonso A.M. (1988), "The effects of truth: re-presentations of the past and the imagining of community", Journal of Historical Sociology, vol. 1, no. 1, pp. 33-57.

7. Wertsch, J.V. (2002), Voices of Collective Remembering, Cambridge University Press, 202p.

8. Wertsch, J.V. \& Roediger, H.L.III (2008), "Collective memory: Conceptual foundations and theoretical approaches", Memory, no. 16, pp.318-326.

9. Vashkevych, V.M. (2013), "Priorities of the history perception by modern youth", National and historical memory [Natsionalna ta istorychna pamiat], no. 6. - pp. 25-31, available at: http://nbuv.gov.ua/j-pdf/Ntip_2013_6_5.pdf (accessed 05 November 2016).

10. Encyclopaedia Britannica (2015), "Holocaust / European History", available at: http://www.britannica.com/event/Holocaust (accessed 09 December 2015).

11. TSN.ua (2010), "Security Service of Ukraine named the ultimate number of Holodomor victims", available at: http://tsn.ua/ukrayina/sbu-nazvala-ostatochnu-kilkist-zhertv-golodomoruv-ukrayini.html (accessed 05 November 2016).

12. BBC.com (2013), "Ten facts about the Holodomor", available at: http://www.bbc.com/ russian/international/2013/11/131122_golodomor_10_facts (accessed 05 November 2016). 
13. Busselle, R. \& Bilandzic, H. (2009), "Measuring narrative engagement", Media Psychology, no. 12 (4), pp. 321-347.

14. Krugman, H.E. (1966), "The measurement of advertising involvement", Public Opinion Quarterly, no. 30 (4), pp. 583-596.

15. Zick, A., Wolf, C., Küpper, B., Davidov, E., Schmidt, P. \& Heitmeyer, W. (2008), "The syndrome of group-focused enmity: The interrelation of prejudices tested with multiple crosssectional and panel data", Journal of Social Issues, no. 64 (2), pp. 363-383.

16. Grimm, J. (2010), "From reality TV to coaching TV. Elements of theory and empirical findings towards understanding the genre", In Hetsroni, A. (ed.), Reality TV. Merging the Global and the Local, New York: Nova Science, pp. 211-258.

17. Schwartz, S.H. (2006), "A theory of cultural value orientations: Explication and applications", Comparative Sociology, no. 5 (2-3), pp. 137-182.

18. Forum for Methods (2007), Value-Hierarchy-Test. Expanded Version, University of Vienna, MF-Working Paper, 2007/01.

19. Craik, F.I.M. (2001), "Memory: Levels of processing", in International Encyclopedia of the Social \& Behavioral Sciences, pp. 9593-9597.

20. Craik, F.I.M. \& Lockhart, R.S. (1972), "Levels of processing: A framework for memory research", Journal of Verbal Learning and Verbal Behavior, no. 11, pp. 671-684.

21. Knowles, E.S., Linn, J.A. (eds.) (2004), Resistance and Persuasion, Taylor \& Francis, New York.

22. Tajfel, H. \& Turner, J.C. (1986), "The social identity theory of intergroup behaviour", In Worchel, S. \& Austin, W.G. (eds.), The Social Psychology of Intergroup Relations, Nelson-Hall, Chicago, pp.7-24.

23. Elias, N. (2000), The Civilizing Process. Revised edition, Blackwell Publishing, Malden, MA and Oxford, $592 \mathrm{p}$.

24. Fahrenberg, J., Hampel, R. \& Selg, H. (1994), Das Freiburger Personlichkeitsinventar: FPI [Freiburg Inventory of Personality], Hogrefe, Gottingen.

25. Grimm, J. (1999), Fernsehgewalt. Zuwendungsattraktivität - Erregungsverläufe sozialer Effekt. Zur Begründung und praktischen Anwendung eines kognitiv-physiologischen Ansatzes der Medienrezeptionsforschung am Beispiel von Gewaltdarstellungen, Westdeutscher Verlag GmbH, Opladen, Wiesbaden.

26. Nussbaum, M.C. (1997), "Kant and cosmopolitanism", In: Bohman, J. \& LutzBachmann, M. (eds.), Perpetual Peace. Essays on Kant's Cosmopolitan Ideal, MIT Press, Cambridge, Mass, pp. 58-77.

27. Nussbaum, M.C. (2001), The Fragility of Goodness. Luck Ethics in Greek Tragedy and Philosophy. Revised edition, Cambridge University Press, Cambridge, London and New York, $544 \mathrm{p}$.

28. Hare, W. (2009), "Socratic open-mindedness", Paideusis, no. 18 (1), pp. 5-16.

29. Higgins, Ch. (2009), "Open-mindedness in three dimensions", Paideusis, no. 18 (1), pp. 44-59.

30. Grimm, J. (2016), Media-Based Holocaust and Holodomor Reception in the Ukraine. Perspectives for a Humanity-Oriented Impartment of History. Contested Memories of the Difficult Past, Kyiv, September 30th - October 1st 2016.

31. Davis, M.H. (1983), "Measuring individual differences in empathy: Evidence for a multidimensional approach", Journal of Personality and Social Psychology, no. 44, pp. 113-126.

32. Davis, M.H., Hull, J.G., Young, R.D. \& Warren, G.G. (1987), "Emotional reactions to dramatic film stimuli: The influence of cognitive and emotional empathy", Journal of Personality and Social Psychology, no. 52 (1), pp. 126-133.

33. Freedberg, D. \& Gallese, V. (2007), "Motion, emotion and empathy in esthetic experience", Trends in Cognitive Sciences, no. 11 (5), pp. 197-203. 